\title{
Analysis of a DVR with Molten Carbonate Fuel Cell and Fuzzy Logic Control
}

\author{
Jaydeep Chakravorty \\ Electrical Engineering Department \\ Indus University \\ Ahmedabad, India
}

\author{
Geena Sharma \\ Electrical Engineering Department \\ Baddi University \\ Himachal Pradesh, India
}

\author{
Vinay Bhatia \\ Electrical \& Electronics Engineering \\ Department, Baddi University \\ Himachal Pradesh India
}

\begin{abstract}
As power demand constantly (and rapidly) increases and with the introduction of many sophisticated electronic devices, power quality issues are becoming a major problem for the power sector. In this context, issues of power quality, voltage swells and sags have become rather common. Custom power devices are generally used to solve this problem. A dynamic voltage restorer (DVR) is the most efficient and effective modern custom power device used in power distribution networks. In this paper a new DVR model is presented. The proposed DVR has a molten carbonate fuel cell (MCFC) as its DC source of supply with an ultra-capacitor along with a fuzzy controller as its controlling unit. The complete model is implemented in MATLAB/SIMULINK and the output of the proposed model is compared with conventional DVR model with a simple DC voltage source and a capacitor with the same fuzzy controller
\end{abstract}

Keywords-DPFC; MCFC; ultra capacitor; fuzzy logic

\section{INTRODUCTION}

As the complexity of power systems increases, voltage swells and sags are becoming common issues. A dynamic voltage restorer (DVR) is considered an economical and very effective device to improve the voltage swell and sag in the system $[1,2]$. DVRs are a class of custom power devices for providing reliable distribution power quality. They employ a series of voltage boost technology using solid state switches for compensating voltage sags/swells. DVRs are mainly used to protect for sensitive loads that may be drastically affected by fluctuations in system voltage. A DVR gives good result when used in the case of low or medium voltage distribution [3, 4]. Other than voltage sags and swells compensation, a DVR can also add other features like: line voltage harmonics compensation, reduction of transients in voltage and fault current limitations. In this paper a new DVR model implemented in MATALB/SIMULINK is presented. The proposed DVR employs a molten carbonate fuel cell (MCFC) as its DC source of supply with an ultra-capacitor along with a fuzzy controller as its controlling unit. The model's behavior is investigated and compared to a more conventional DVR model.

\section{MOLTEN CARBONATE FUEL CELL}

The schematic model of a Molten Carbonate Fuel Cell (MCFC) is shown in Figure 1. A fuel cell converts chemical energy into electrical energy. In the $\mathrm{MCFC}$, the $\mathrm{CO}_{2}$ gas moves from cathode to anode through a molten electrolyte. Here molten carbonate salt acts as an electrolyte where two porous electrodes are present. The electrode layer is formed in sub layers. Between the gas and the electrode a thin porous metal plate is inserted acting as a diffuser, it helps in helping the gas mixture to enter the porous electrode. When the $\mathrm{CO}_{2}$ combines with $\mathrm{O}_{2}$ in the cathode gives carbonate ions and when it combines with hydrogen in the anode side it gives $\mathrm{CO}_{2}$ and $\mathrm{H}_{2} \mathrm{O}$. So there will be a movement of electrolyte from anode side to the cathode side. The gas reaction at the anode side is

$$
\mathrm{CO}+\mathrm{H}_{2} \mathrm{O} \leftrightarrow \mathrm{CO}_{2}+\mathrm{H}_{2}
$$

The electrochemical half reaction is

$$
\mathrm{H}_{2}+\mathrm{CO}_{3}^{--} \leftrightarrow \mathrm{CO}_{2}+\mathrm{H}_{2} \mathrm{O}+2 e
$$

Similarly the equation of cathode side will be

$$
\frac{1}{2} \mathrm{O}_{2}+\mathrm{CO}_{2}+2 e \leftrightarrow \mathrm{CO}_{3}^{--}
$$

The equivalent electrical circuit of a singular cell MCFC is shown in Figure 2 [5], where, $R_{i}$ is the ionic resistance, $R_{e}$ is the electronic resistance and $\mathrm{R}_{\text {load }}$ is the external load resistance. Electrically, a single cell acts as the parallel of elementary real generators, each of which is a fraction of the cell thickness from anode to the cathode. If the fuel cell is having generic $(\mathrm{N}, \mathrm{k})$ strip, where, $\mathrm{N}=1,2, \ldots \ldots \ldots \mathrm{N}_{\mathrm{chA}}$ and $\mathrm{k}=1,2, \ldots \ldots \ldots \mathrm{N}_{\mathrm{chc}}$ ) then the total current flow and also the potential difference is given by:

$$
\begin{aligned}
& i_{\text {load }}=\sum_{N=1, k=1}^{N c h a, N c h c} i_{N, k} \\
& V_{\text {out }}=E-i_{N . k} \times R_{\text {load }}=i_{\text {load }} \times R_{\text {load }}
\end{aligned}
$$

where, $\mathrm{E}$ is the Nernst voltage of $(\mathrm{N}, \mathrm{k})$ strip, and is given by:

$$
E=E_{0}+\frac{R T}{2 F} \ln \left(\frac{P_{\mathrm{H} 2} P_{02}^{0.5}}{P_{\mathrm{H} 2 \mathrm{O}}} \times P_{\mathrm{CO} 2}\right)
$$

where, $E_{0}$ is the standard condition potential and the neutral component concentrations refer to the gas diffused into the liquid electrolyte. Single cell voltage is given by (7) [5]:

$$
V_{c}=\frac{E_{m}-\eta_{f} \times i_{m} \times R_{i}}{\frac{R_{i}}{R_{e}} \times\left(1-\eta_{f}\right)+1}=E_{r}-i\left(\mu_{a}+\mu_{c}+\mu_{o}\right)
$$


where, $E_{r}$ is the reversible voltage of the cell, $\mu_{\alpha}$ the activation voltage, $\mu_{\mathrm{c}}=-\mathrm{V}_{\mathrm{CO}}$ the concentration voltage, $\mu_{0}=-\mathrm{V}_{0}$ the ohmic voltage.

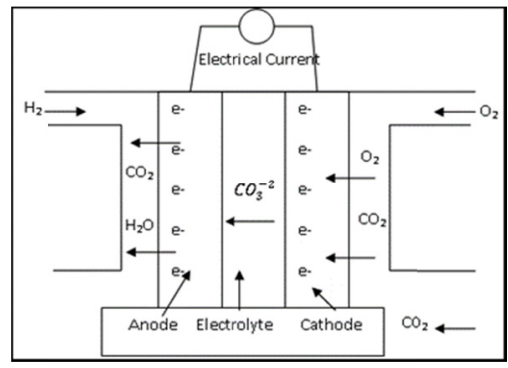

Fig. 1. Molten carbonate fuel cell.

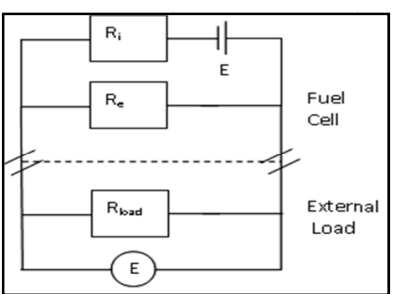

Fig. 2. Electrical equivalent of MCFC

Again,

$E_{r}=1.2-9 \times 10^{-4}(T-298)+T 4.3 \times 10^{-5}\left(\ln P_{\mathrm{H}_{2}}+\frac{1}{2} \ln P_{\mathrm{CO}_{2}}\right)$

$\mu_{a}=2.3 \times 10^{-10} \times P_{\mathrm{H} 2} \times P_{\mathrm{CO} 2} \times P_{\mathrm{H} 2 o} \times e^{\left(\frac{E}{R T}\right)} \quad$ is $\quad$ the activation polarization losses, $\mu_{c}=7.5 \times 10^{-10} \times P_{o 2} \times$ $P_{C O 2} \times e^{\left(\frac{E}{R T}\right)}$ the concentration polarization losses and $\mu_{0}=$ $0.45 \times 10^{-5} e^{\left(8600 \times\left(\frac{1}{T}-\frac{1}{925}\right)\right)}$ the ohmic polarization loss. where,

$$
\begin{gathered}
P_{\mathrm{H} 2}=0.5 P_{\mathrm{H} 2 \mathrm{O}}\left(\exp \left(-\frac{1.635 \mathrm{~J}}{T^{1.334}}\right) \frac{P_{a}}{P_{\mathrm{H} 2 \mathrm{O}}}-1\right) \\
P_{\mathrm{O} 2}=P_{\mathrm{H} 2 \mathrm{O}}\left(\exp \left(-\frac{4.192 J}{T^{1.334}}\right) \frac{P_{C}}{P_{\mathrm{H} 2 \mathrm{O}}}-1\right) \\
P_{\mathrm{CO}_{2}}=\frac{P_{\mathrm{O}_{2}}}{5.08 \times 10^{6} \times e^{-498 / T}}
\end{gathered}
$$

$\log P_{\mathrm{H}_{2} \mathrm{O}}=-2.18+2.95 \times 10^{-2} T_{C}-9.18 \times 10^{-5} T_{C}^{2}+1.44 \times 10^{-7} T_{C}^{3}$

where, $T_{c}=T-274$. The thermal capacitance for all the volume or mass of the fuel $=10 \mathrm{~J} / \mathrm{K}$ is expressed by (12):

$$
C t \frac{d T}{d t}=i\left(E_{r}-V_{c}\right)-H\left(T-T_{f}\right)
$$

where, $H$ is the total heat transfer coefficient $(10 \mathrm{~W} / \mathrm{K}), T_{f}$ the reference temperature $(300 \mathrm{~K}), P_{a}$ the partial pressure for anode (1.5), $P_{c}$ the partial pressure for cathode (1) and $J$ the current density (1). The kinetic equation of the chemical reaction in MCFC is tabulated in Table I. The physical properties and the operating conditions are tabulated in Tables II and III respectively. The complete detail of the mathematical model is tabulated in Table IV.
TABLE I. CHEMICAL REACTION WITH KINETIC EQUATION

\begin{tabular}{|l|c|}
\hline \multicolumn{1}{|c|}{ Chemical Reactions } & Kinetic Equation \\
\hline $\mathrm{CH}_{4}+\mathrm{H}_{2} \mathrm{O} \rightarrow \mathrm{CO}+3 \mathrm{H}_{2}$ & $R_{1}=\frac{\frac{K_{1}}{P_{H 2}^{2.5}}\left(P_{C H_{4}} P_{H_{2} \mathrm{O}}-\frac{P_{H 2}^{3} P_{C O}}{K_{e q 1}}\right)}{D^{2}}$ \\
\hline $\mathrm{CO}+\mathrm{H}_{2} \mathrm{O} \rightarrow \mathrm{H}_{2}+\mathrm{CO}_{2}$ & $R_{2}=\frac{\frac{K_{2}}{P_{H_{2}}}\left(P_{C O} P_{H_{2} \mathrm{O}}-\frac{P_{C O} P_{H_{2}}}{K_{e q 2}}\right)}{D^{2}}$ \\
\hline $\mathrm{CH}_{4}+2 \mathrm{H}_{2} \mathrm{O} \rightarrow \mathrm{CO}_{2}+4 \mathrm{H}_{2}$ & $R_{3}=\frac{\frac{K_{3}}{P_{H 2}^{3.5}}\left(P_{C H_{4}} P_{H_{2} \mathrm{O}}^{2}-\frac{P_{H 2}^{4} P_{C O 2}}{K_{e q 3}}\right)}{D^{2}}$ \\
\hline$K_{i}=K_{i T r} e^{\left(\frac{-E_{i}}{R} \times\left(\frac{1}{T}-\frac{1}{T r}\right)\right)}$ & $K_{j}=K_{j T r} e^{\left(\frac{-\Delta h_{j}}{R} \times\left(\frac{1}{T}-\frac{1}{T r}\right)\right)}$ \\
\hline
\end{tabular}

TABLE II. PHYSICAL PROPERTIES

\begin{tabular}{|c|c|c|c|c|}
\hline Property & Cathode & Anode & Electrolyte & Separator \\
\hline $\begin{array}{c}\text { Density } \\
\left(\mathrm{Kg} / \mathrm{m}^{3}\right)\end{array}$ & 6000 & 8000 & 2000 & 8100 \\
\hline $\begin{array}{c}\text { Heat capacity } \\
\left(\mathrm{J} . \mathrm{Kg}^{-1} \mathrm{~K}^{-1}\right)\end{array}$ & 43000 & 390 & 4890 & 520 \\
\hline $\begin{array}{c}\text { Heat } \\
\text { Conduction } \\
\left(\mathrm{W} \cdot \mathrm{m}^{-1} \cdot \mathrm{K}^{-1}\right)\end{array}$ & 3 & 30 & 30 & 30 \\
\hline
\end{tabular}

\begin{tabular}{|c|c|}
\hline Domain & Boundary \\
\hline $\begin{array}{c}C\left(\frac{\delta x_{A}}{\delta t}+V_{x} \frac{\delta x_{A}}{\delta x}\right)=\frac{1}{V_{c h}} \sum_{j}\left(R_{A j}-\right. \\
\left.x_{A} \sum_{\beta=1}^{N} R_{\beta j}\right)\end{array}$ & $\begin{array}{l}x_{A}(x=0, t)=x_{A 0} \\
x_{A}(x, t=0)=x_{A i}\end{array}$ \\
\hline $\begin{array}{l}C C_{p}\left(\frac{\delta T_{a c}}{\delta T}+V_{s} \frac{\delta T_{a c}}{\delta x}\right)= \\
\frac{q_{a c}}{V_{c h}}-\frac{1}{V_{c h}} \sum R_{j} \Delta h_{j} \\
q_{T}=q_{a c}+\sum R_{j} \Delta h_{j} \quad q_{c} \\
=A h_{c}\left(T_{s}-T_{c}\right) \\
q_{a}=A h_{a s}\left(T_{s}-T_{a}\right) \\
n_{s} C_{p s} \frac{\delta T_{s}}{\delta t}=K_{s}\left(\frac{\delta^{2} T_{s}}{\delta x^{2}}\right) \\
-\frac{R_{\text {elec }} \Delta h_{\text {elect }}-i V_{\text {cea }}}{V_{s}} \\
-\frac{A\left(h_{a s} \times\left(T_{s}-T_{a}\right)+h_{c s} \times\left(T_{s}-T_{a}\right)\right)}{V_{s}}\end{array}$ & $\begin{array}{l}T_{a c}(x=0, t) \\
=T_{a c, 0} \\
T_{a c}(x, t=0) \\
=T_{a c i} \\
\frac{\delta T_{s}}{\delta x}=(x=0, t) \\
=0 \\
\frac{\delta T_{s}}{\delta x}=(x=L, t) \\
=0 \\
T_{s}(x, t=0)=T_{s, i}\end{array}$ \\
\hline
\end{tabular}

TABLE III. CONDITIONS

\begin{tabular}{|c|c|}
\hline Simulated Parameters & Values \\
\hline Operating pressure & $1 \mathrm{bar}$ \\
\hline Thickness (Cell) & $1 \mathrm{~cm}$ \\
\hline Thickness (Electrode) & $1 \mathrm{~mm}$ \\
\hline Thickness (Electrolyte) & $1 \mathrm{~mm}$ \\
\hline Area & $1 \mathrm{~m} \mathrm{x} \mathrm{1m}$ \\
\hline Convection coefficient (Anode) & $84 \mathrm{Wm}-2 \mathrm{~K}-1$ \\
\hline Convection coefficient (Cathode) & $90 \mathrm{Wm}-2 \mathrm{~K}-1$ \\
\hline Activation energy (Anode) & $50000 \mathrm{Jmol}-1 \mathrm{~K}-1$ \\
\hline Activation energy (Cathode) & $70000 \mathrm{Jmol}-1 \mathrm{~K}-1$ \\
\hline Heat capacity (Anode) & $4 \mathrm{R}$ \\
\hline Heat capacity (Cathode) & $4 \mathrm{R}$ \\
\hline
\end{tabular}

TABLE IV. MATHEMATICAL MODEL OF MCFC 
The equations are integrated along the anodic and cathodic $\mathrm{x}$ coordinate. Equations regarding catalytic medium are integrated along the $\mathrm{z}$ coordinate. [6]. ODEs are thus obtained from PDEs. This conversion decreases the complexity of the equations but on the other hand the volume of the equations increases. The ODEs are time discretized to obtain the approximate equations. These equations are then solved using iterative techniques. Thus the obtained ODEs are then simulated in MATLAB. For solving these equations, the ode23s MATLAB solver was selected. The SIMULINK model of various parts of MCFC is shown in Figures 3-8.

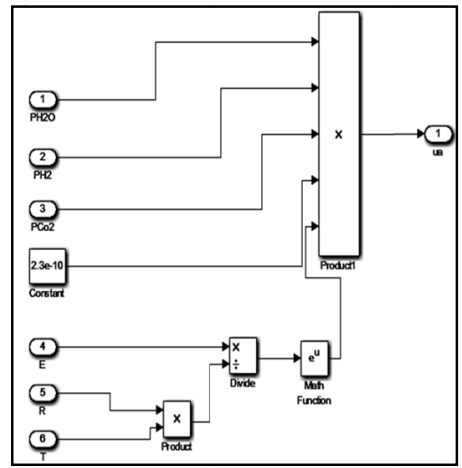

Fig. 3. Ohmic polarization loss model

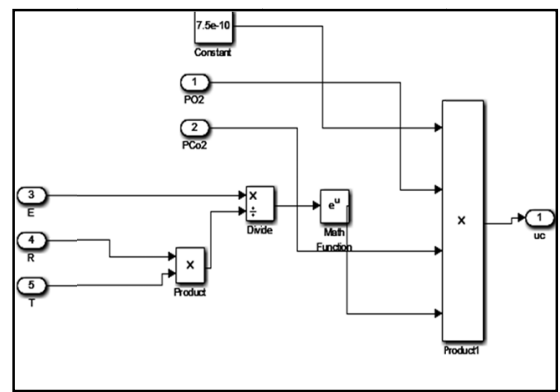

Fig. 4. Concentration polarizatio loss model.

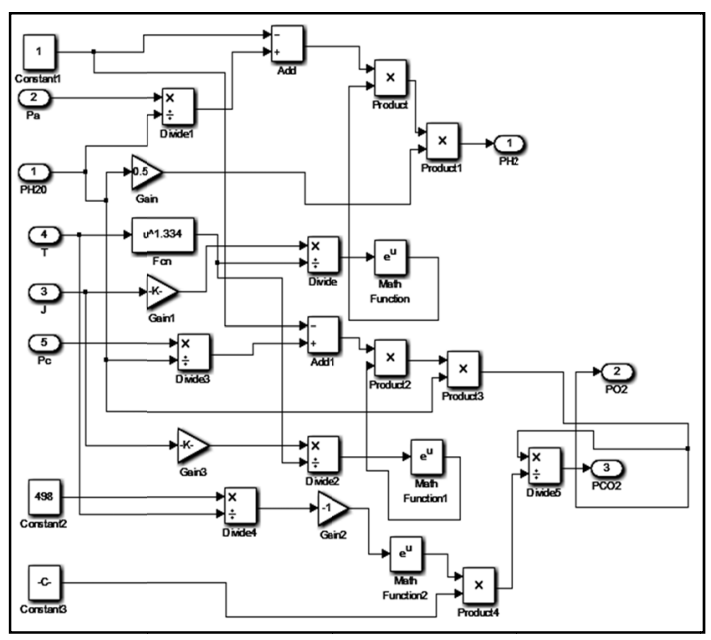

Fig. 5. Ohmic polarization loss model

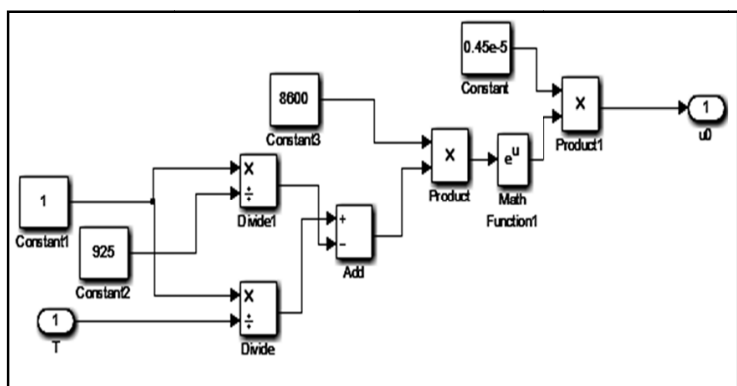

Fig. 6. $\quad \mathrm{PH}_{2}, \mathrm{PO}_{2}, \mathrm{PCO}_{2}$ model

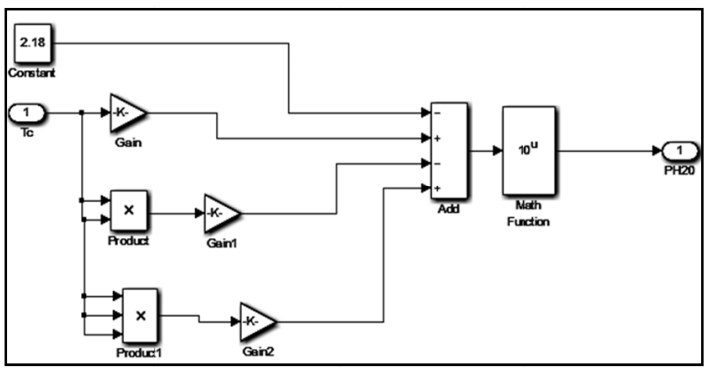

Fig. 7. $\quad \mathrm{PH}_{2} \mathrm{O}$ model

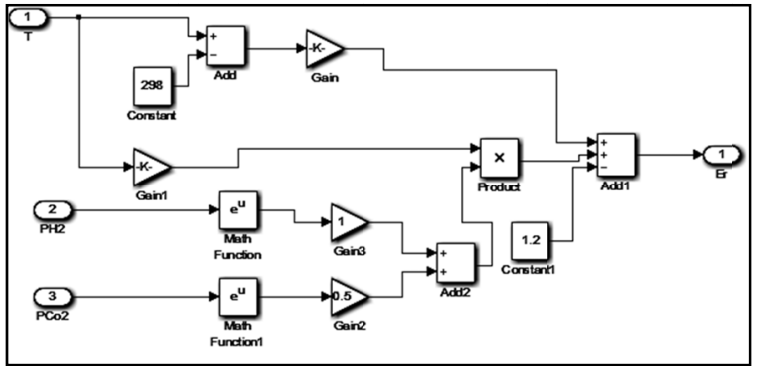

Fig. 8. Reversible voltage model

\section{Ultra CAPACitor}

Capacitor is a device used to store the charge in an electric circuit. An ultra-capacitor, also known as super capacitor is an electrical component capable of holding hundreds of times more electrical charge quantity than a standard capacitor. Unlike batteries, no chemical reaction takes place when energy is being stored or discharged and therefore an ultra capacitor can go through thousands of charging cycles with no degradation. Energy is stored in it by polarizing the electrolytic solution. The charges are separated via electrode-electrolyte interface. Ultra capacitor consists of a porous electrode, electrolyte and a current collector (metal plates). There are two carbon sheets separated by separator. The highly porous carbon can store more energy than any other electrolytic capacitor. When the voltage is applied to the negative plate, it attracts the positive ions from the electrolyte and when the voltage is applied to the positive plate, it attracts the negative ions from the electrolyte. Therefore there is a formation of a layer of ions on both plate sides and hence it is also called double layer capacitor. Capacitors are complementary to batteries as they deliver high power density and low energy density. The super 
capacitor is a solution where ambient temperatures make it difficult to keep batteries inside the recommended operating range without compromising their capacity and lifetime. Super capacitor has high power and energy density, and therefore much higher efficiency. Conventional capacitors use dielectrics to increase capacitance by allowing plates to get very close. However practical problems on plate surface area and distance between plates reduce capacity. This drawback is overcomed by a super capacitor which provides large surface area with distance. Authors in [8] designed super capacitor based storage systems for elevator applications. The comparison between a battery and a super-capacitor is broken down in Table $\mathrm{V}$.

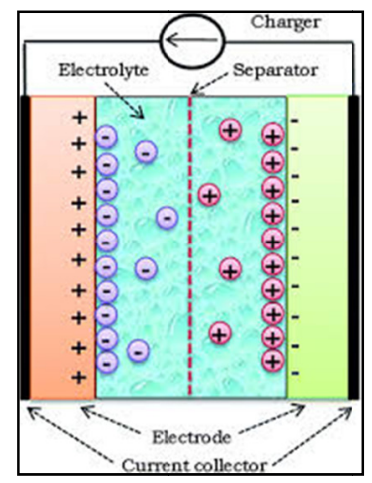

Fig. 9. Ultra capacitor

TABLE V. BATTERY - SUPER CAPACITOR COMPARISON

\begin{tabular}{|c|c|c|}
\hline Features & Battery & Super capacitor \\
\hline Power Range & Up to megawatts & $\begin{array}{c}\text { Up to tens of thousands } \\
\text { of kilowatts }\end{array}$ \\
\hline Reliability & Moderate & High \\
\hline Recharge time & $10 x$ discharge time & Seconds \\
\hline $\begin{array}{c}\text { Number of } \\
\text { discharge cycles }\end{array}$ & Up to 3000 & Up to 1 million \\
\hline $\begin{array}{c}\text { Operating } \\
\text { Conditions }\end{array}$ & $\begin{array}{c}\text { Narrow } \\
\text { temperature range }\end{array}$ & Wide temperature range \\
\hline
\end{tabular}

\section{FUZZY CONTROLLER}

In DVR the PI controller is the most common controller of the proper DVR operation. But efficiency of the PI controller decreases with an increase in the DVR range of operation. Nowadays, Fuzzy logic is being used in DVR control. This increases the efficiency and the reliability of the system to a greater extent. The fuzzy rules used are shown in Table VI. The phase of the voltage of the network is determined using a phase lock loop (PLL). After determination of the phase a reference signal of unity is generated to supply frequency for each phase of the system. The difference between reference signal of PLL and the actual supply voltage gives the error signal. So, the two inputs for the fuzzy controller are the error and the error rate. The output of the fuzzy controller when passing through PWM gives the pulse.

\section{PROPOSED MODEL}

The single line diagram of the system under test is shown in Figure 10. From the source, two parallel feeders are taken out. One of the feeders is connected with the DVR under test and the other feeder is not. The DVR has three operating modes, protection mode, standby mode and boost mode [9]. The DVR model has a source and a storage unit, a capacitor, inverter circuit and a filter circuit. In the proposed model, the MCFC has been used as a source for DVR along with ultra capacitor. The inverter circuit has IGBT in it and the filter circuit is an LC filter. The main function of the filter circuit is to keep the harmonic voltage generated by the power electronic devices present in the DVR to an acceptable value. The system parameters used for testing are given in Table VII. Two systems have been designed. First, the DVR model with simple DC source and a capacitor with fuzzy controller. The other, is the proposed DVR with MCFC as a source of supply and with ultra capacitor. The controller in both the system is kept the same.

TABLE VI. FUZZY RILES

\begin{tabular}{|c|c|c|c|c|c|c|c|}
\hline $\mathbf{e} / \mathbf{\Delta} \mathbf{e}$ & $\mathbf{P L}$ & $\mathbf{P M}$ & $\mathbf{P S}$ & $\mathbf{Z}$ & $\mathbf{N L}$ & $\mathbf{N M}$ & $\mathbf{N S}$ \\
\hline $\mathbf{P L}$ & PL & PL & PL & PM & PM & PS & Z \\
\hline PM & PL & PL & PM & PM & PS & Z & NS \\
\hline PS & PL & PM & PM & PS & Z & NS & NM \\
\hline $\mathbf{Z}$ & PL & PL & PS & Z & NS & NM & NM \\
\hline NL & PM & PS & Z & NS & NM & NM & NM \\
\hline NM & PS & Z & NS & NM & NM & NM & NM \\
\hline NS & Z & NS & NM & NM & NL & NL & NL \\
\hline
\end{tabular}

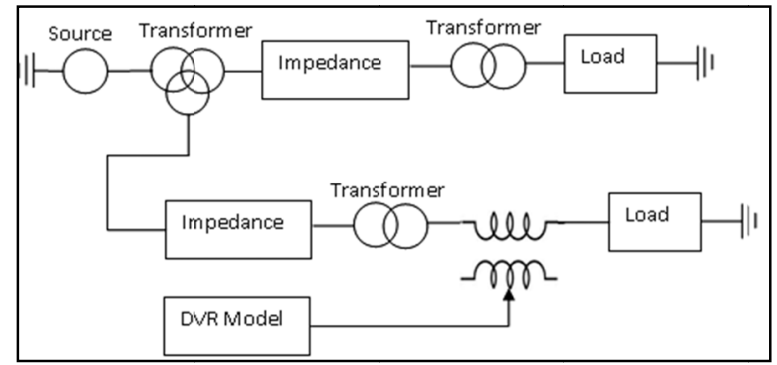

Fig. 10. Block diagram of test system

TABLE VII. TESTING PARAMETERS

\begin{tabular}{|c|c|}
\hline Parameter & Value \\
\hline Source & $11 \mathrm{KV}, 50 \mathrm{~Hz}, 3$ Phase \\
\hline Inverter & $\begin{array}{c}\text { IGBT, } 6 \text { pulse, } 3 \text { arm, carrier } \\
\text { frequency }=1080 \mathrm{~Hz} \text {, Time } 4 \mu \mathrm{sec} \text {. }\end{array}$ \\
\hline Load & $\begin{array}{c}\text { Active power of } 1 \mathrm{KW} \text {, Reactive power of } \\
500 \mathrm{VAR}\end{array}$ \\
\hline $\begin{array}{l}\text { Two winding } \\
\text { transformer }\end{array}$ & $11 \mathrm{KV} / 415 \mathrm{~V}$ \\
\hline $\begin{array}{l}\text { Three winding } \\
\text { transformer }\end{array}$ & $11 \mathrm{KV} / 415 \mathrm{~V} / 415 \mathrm{~V}$ \\
\hline
\end{tabular}

\section{PROPOSED SIMULINK MODEL}

The complete SIMULINK model of the MCFC after combining all the subsystems discussed above is shown in Figure 11. The models of ultra capacitor, fuzzy controller, complete DVR with simple voltage source and the proposed model of DVR with MCFC and ultra-capacitor are shown Figure 12, 13, 14 and 15 respectively. 


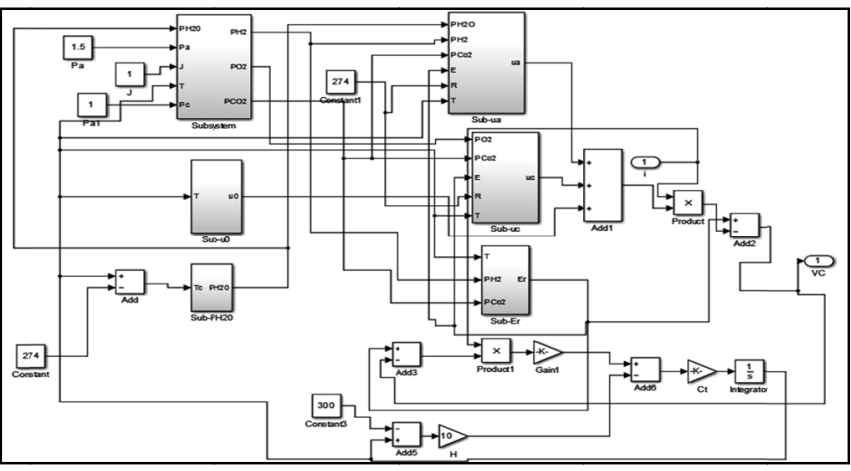

Fig. 11. MCFC SIMULINK model

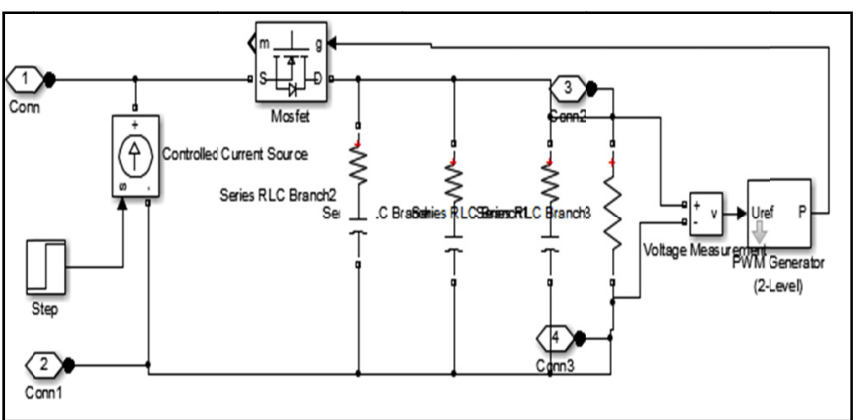

Fig. 12. Ultra capacitor SIMULINK model

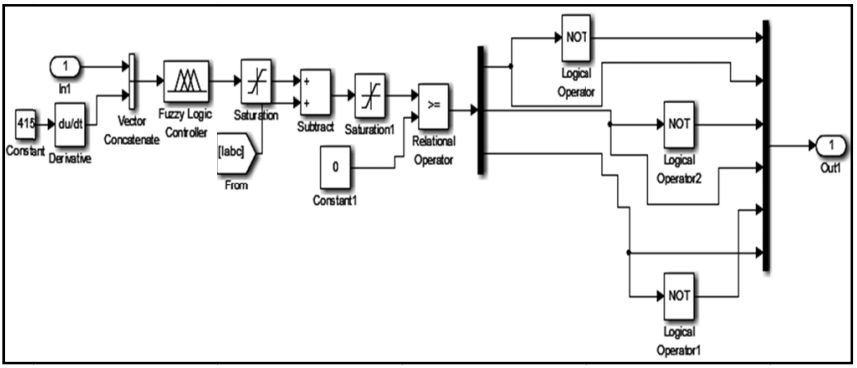

Fig. 13. Fuzzy controller SIMULINK model

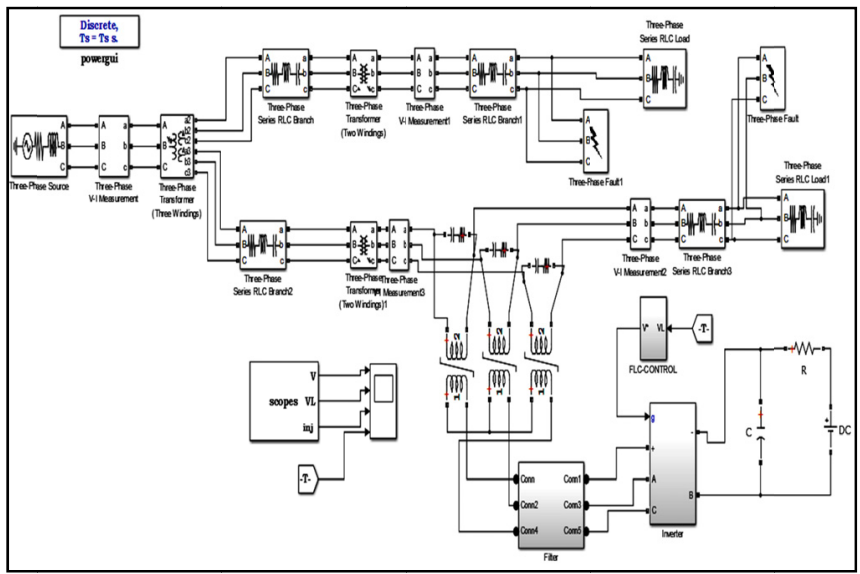

Fig. 14. DVR with sinple voltage source and capacitor SIMULINK model.

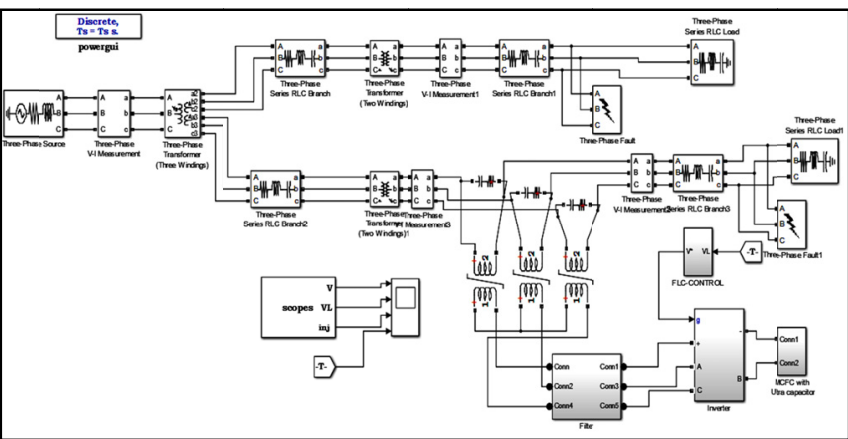

Fig. 15. DVR with MCFC and ultra capacitor.

\section{SIMULATED RESULTS}

Before using the MCFC model in our proposed DVR, the behavior of the MCFC was compared with the experimental data available in the literature [7]. Results are shown in Figure 16. The behavior of the circuit, without DVR and with DVR (conventional model, Figure 14), for different fault conditions is described in Figures 17 to 25. The corresponding output waveform of the proposed DVR model with MCFC and ultracapacitor for different fault conditions is shown in Figures 26 to 28 . The comparative table for the two models is given in Table VIII.

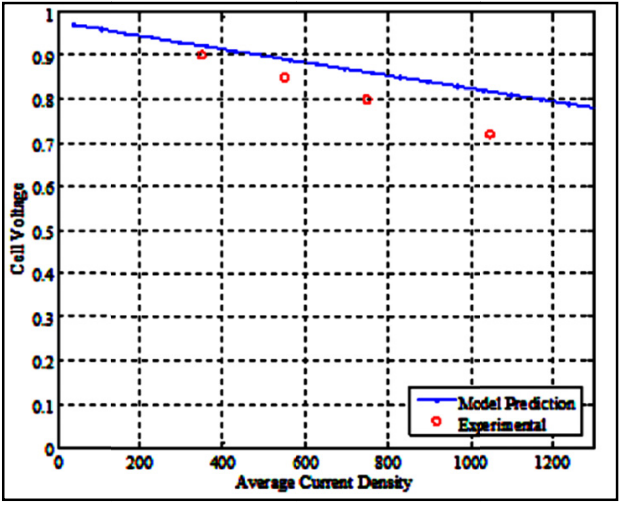

Fig. 16. Comparative graph

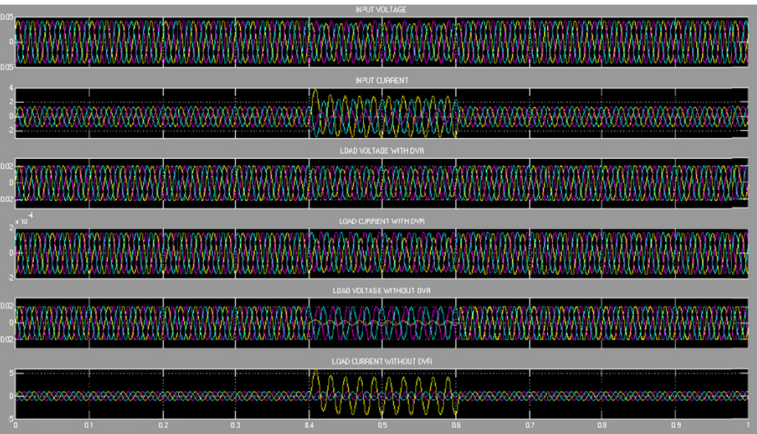

Fig. 17. Single line to ground fault. 


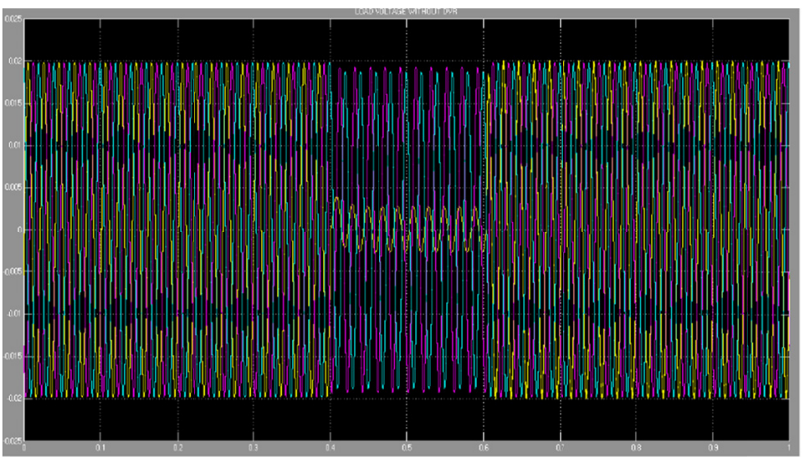

Fig. 18. Load votage without DVR

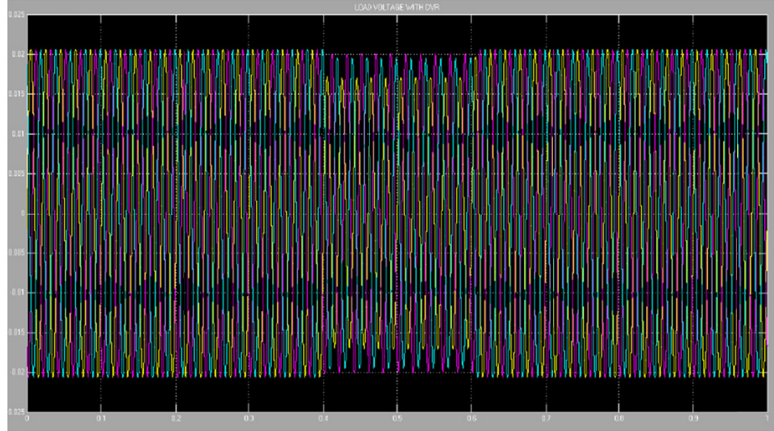

Fig. 19. Load voltage with DVR

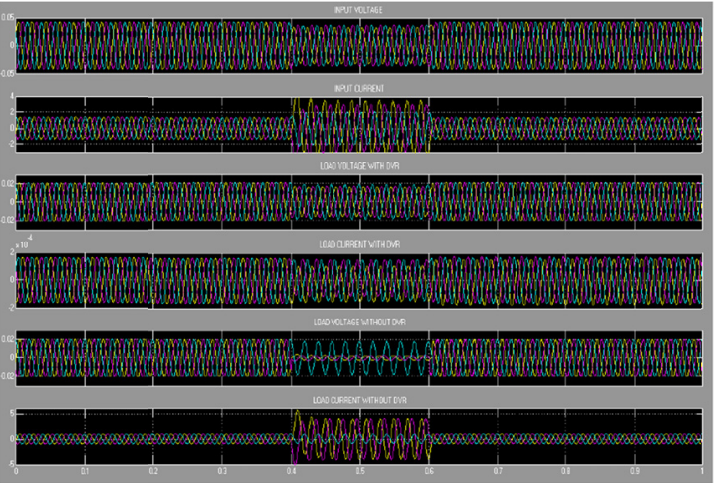

Fig. 20. Double line to ground fault

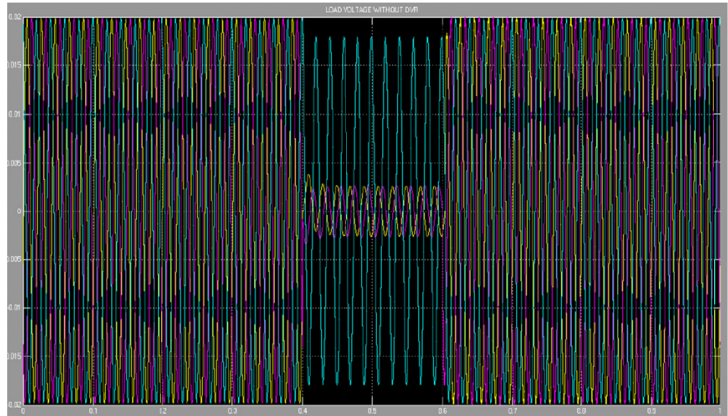

Fig. 21. Load voltage without DVR

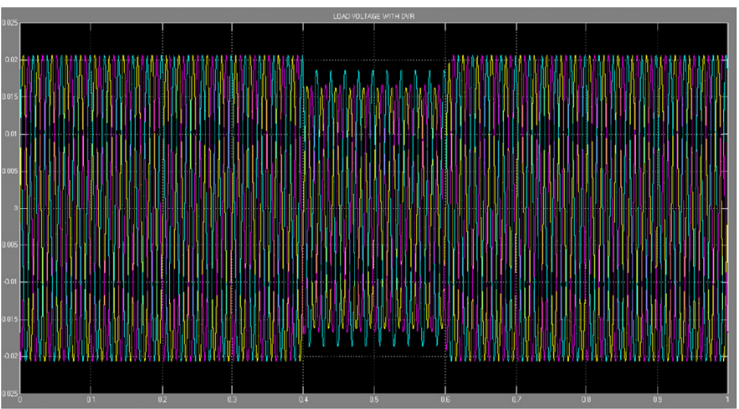

Fig. 22. Load voltage with DVR

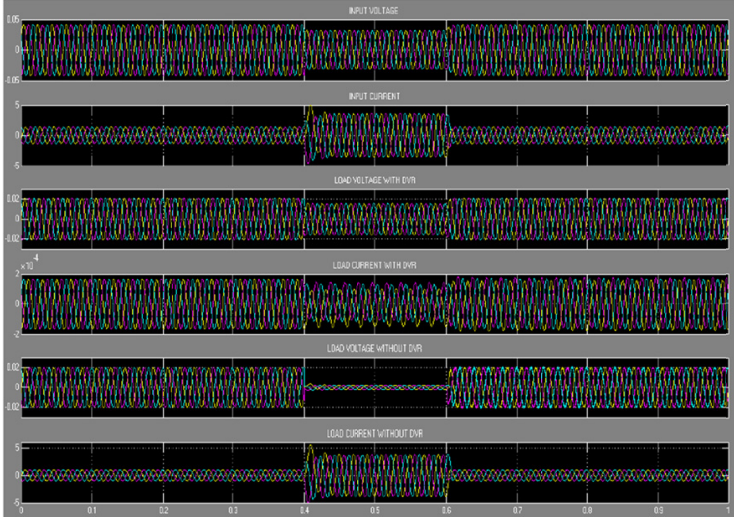

Fig. 23. Three phase to ground fault

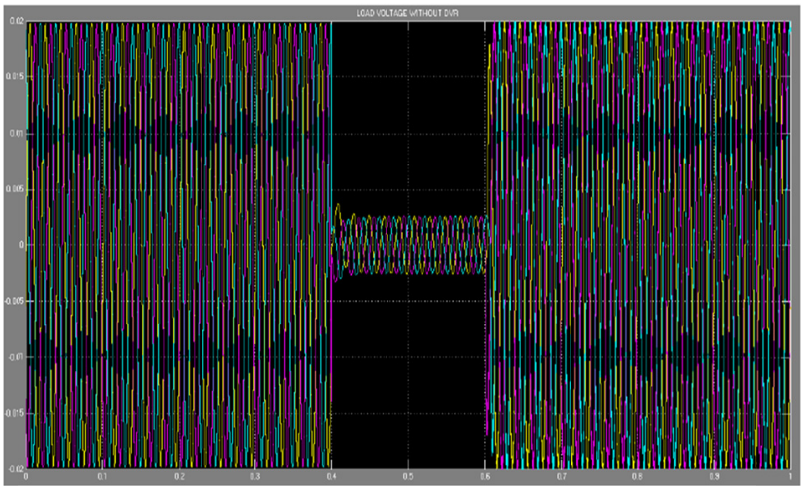

Fig. 24. Load voltage without DVR

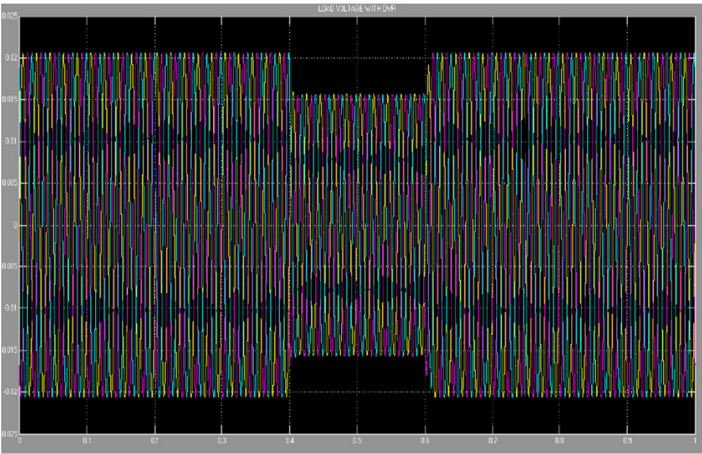

Fig. 25. Load voltage with DVR 


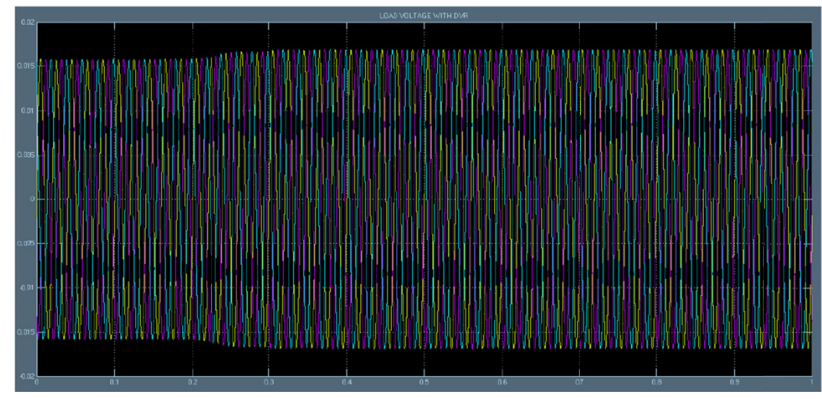

Fig. 26. Load voltage (single line to ground fault)

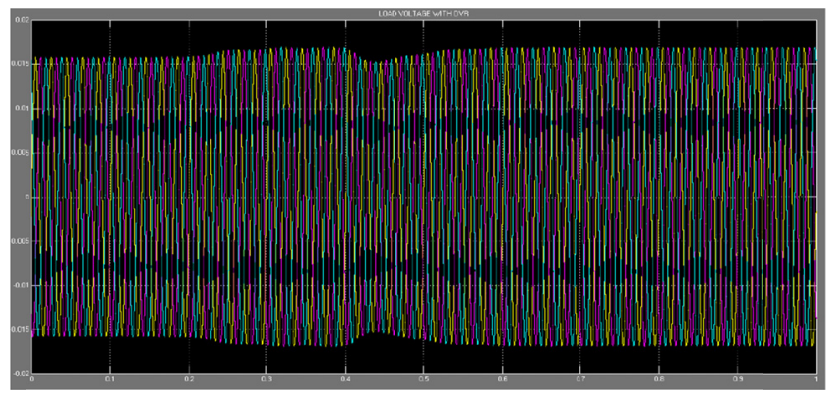

Fig. 27. Load voltage (Double line to ground fault)

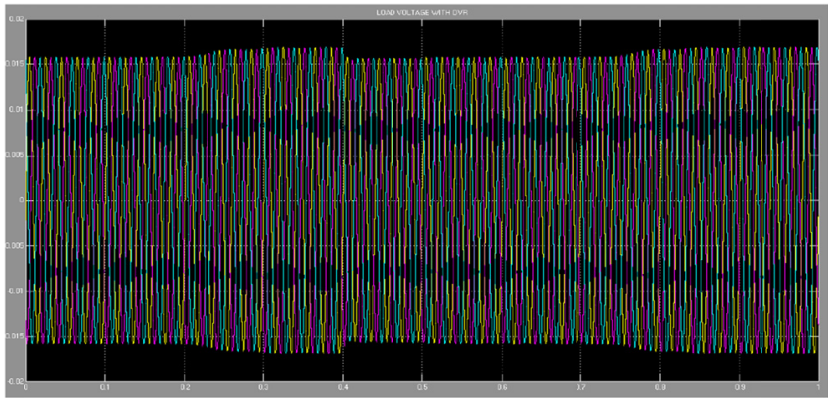

Fig. 28. Load voltage (three phase to ground fault)

TABLE VIII. COMPARISON OF THE TWO METHODS

\begin{tabular}{|c|c|c|c|}
\hline & Phase & $\begin{array}{c}\text { Conventional } \\
\text { model (Figure 14) }\end{array}$ & $\begin{array}{c}\text { Proposed model } \\
\text { (Figure 15) }\end{array}$ \\
\hline \multirow{2}{*}{$\begin{array}{c}\text { Distorted } \\
\text { voltage }\end{array}$} & $\mathrm{A}$ & 232 & 232 \\
\cline { 2 - 4 } & $\mathrm{B}$ & 234 & 234 \\
\cline { 2 - 4 } & $\mathrm{C}$ & 232 & 232 \\
\hline \multirow{2}{*}{$\begin{array}{c}\text { Injected } \\
\text { voltage }\end{array}$} & $\mathrm{A}$ & 158 & 183 \\
\cline { 2 - 4 } & $\mathrm{B}$ & 152 & 181 \\
\cline { 2 - 4 } & $\mathrm{C}$ & 137 & 183 \\
\hline \multirow{2}{*}{$\begin{array}{c}\text { Load } \\
\text { voltage }\end{array}$} & $\mathrm{A}$ & 390 & 415 \\
\cline { 2 - 4 } & $\mathrm{B}$ & 386 & 415 \\
\cline { 2 - 4 } & $\mathrm{C}$ & 369 & 415 \\
\hline
\end{tabular}

\section{CONCLUSION}

The proposed DVR was tested for different fault conditions. From the obtained results, it can be concluded that the proposed DVR with MCFC and ultra capacitor is more efficient when compared to a conventional DVR design. However, it should be noted that conventional model took less simulation time to execute. The ode $23 \mathrm{~s}$ solver was selected even though it resulted to low speed since the odc 15 s solver proved even slower and the ode $23 \mathrm{t}$ and ode 23 tb solvers gave convergence problem. Overall results show that the MCFC based DVR with fuzzy control could be an efficient solution for the improvement of power quality in the power system.

\section{REFERENCES}

[1] C. Sankaran, PowerQuality, CRC Press, 2001

[2] R. C. Dugan, S. Santoso, M. F. McGranaghan, H. W. Beaty, Electrical Power Systems Quality, McGraw Hill Professional, 2012

[3] T. Jimichi, H. Fujita, H. Akagi, "Design and experimentation of a dynamic voltage restorer capable of significantly reducing an energystorage element", IEEE Transactions on Industry Applications, Vol.44, No.3, pp.817-825, 2008

[4] C. Gopinath, R. Ramesh, "Dynamic voltage restorer using ultra storage capacitor", International Conference on Sustainable Energy and Intelligent Systems, Chennai, India, pp.69-74, July 20-22, 2011

[5] J. Milewski, A. Miller, "Influences of the type and thickness of electrolyte on solid oxide fuel cell hybrid system performance", Journal of Fuel Cell Science and Technology, Vol. 3, No. 4, pp. 396-402, 2006

[6] D. Flynn, Modelling of power plant in Thermal Power Plant Simulation and Control, The Institution of Electrical Engineers, 2003

[7] J. Brouwer, F. Jabbari, E. M. Leal, T. Orr, "Analysis of a molten carbonate fuel cell: Numerical modeling and experimental validation", Journal of Power Sources, Vol. 158, No. 1, pp. 213-224, 2006

[8] S. Luri, I Etxeberria-Otadui, A. Rujas, E. Bilbao, A. Gonzalez, "Design of Supercapacitor based storage system for improved elevator application", IEEE Energy Conversion Congress and Exposition, Atlanta, USA, pp. 4534-4539, September 12-16, 2010

[9] J. G. Nielsen, F. Blaabjerg, N. Mohan, "Control strategies for dynamic voltage restorer compensating voltage sags with phase jump", 16th Annual IEEE Applied power electronics conference and exposition, Anaheim, USA, Vol. 2, pp. 1267-1273, March 4-8, 2001 